\title{
Institutional disruption and technology platforms: the Uber case
}

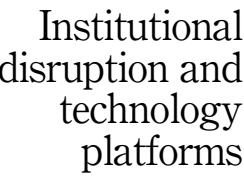

\author{
Wilquer Silvano de Souza Ferreira, Gláucia Maria Vasconcellos Vale \\ and Patrícia Bernardes \\ Programa de Pós-Graduação em Administração - PPGA/PUC Minas, \\ Pontificia Universidade Catolica de Minas Gerais, Belo Horizonte, Brazil
}

\begin{abstract}
Purpose - The aim of this article is to test the hypothesis that peer-to-peer technology platforms (Uber) are associated with disruption in the institutional environment, affecting beliefs, norms and users' ways of thinking and acting.

Design/methodology/approach - Probability sample comprising 843 users (446 passengers; 397 drivers) in the city of Belo Horizonte, Brazil, using a set of indicators was specifically designed for this study.

Findings - Uber triggers significant changes in the systems of rewards and sanctions, in social preferences, and in entrepreneurial structure and governance, and promotes the coexistence of an institutional logic, hitherto dominant, with new believes, rules, norms and regulatory systems.

Originality/value - This is a pioneer study that associates institutional approach's elements with technology platforms; the authors also elaborated and utilized an analysis model consisting of a set of completely original indicators capable of mapping and measuring different dimensions of the phenomenon under analysis.
\end{abstract}

Keywords Institutional disruption, Social practices, Technology platforms, Peer-to-peer, Uber

Paper type Research paper

\section{Introduction}

New technologies have triggered over the past years several disturbances in the socioeconomic environment with significant impacts on the institutional sphere, modifying the way people relate, allocate available resources, perform daily activities and formulate "rules and requirements to which individual organizations must conform if they are to receive support and legitimacy" (Scott, 1995, p. 132).

Such institutional disruption can be perceived in different dimensions of social and economic life, especially considering the urban mobility segment-in which Uber is to be found-with the emergence of technology platforms and collaborative consumption. The quick proliferation of hitchhiking and mobility applications has been affecting not only the organizational environment, but also the way through which individuals relate to each other and the nature of social preferences, which is a process still poorly known and mapped.

To understand the capitalist economic institutions and their changes has become a challenge in the fields of economics, law studies, organizations, sociology, among others.

Wilquer Silvano de Souza Ferreira, Gláucia Maria Vasconcellos Vale and Patrícia Bernardes. Published in Revista de Gestão. Published by Emerald Publishing Limited. This article is published under the Creative Commons Attribution (CC BY 4.0) licence. Anyone may reproduce, distribute, translate and create derivative works of this article (for both commercial and non-commercial purposes), subject to full attribution to the original publication and authors. The full terms of this licence may be seen at http:// creativecommons.org/licences/by/4.0/legalcode 
The institutional theories assume that institutions have a central logic (Friedland \& Alford, 1991) or rationality (DiMaggio \& Powell, 1983; Scott, 1995; Townley, 2002), endowed with a set of material and symbolical practices in addition to organizational principles that provide action logics for individuals and organizations (Glynn \& Lounsbury, 2005; Suddaby \& Greenwood, 2005). However, institutions are dynamic and evolve over time according to certain conditions or circumstances.

Some studies examine how an institutional logic could be replaced by a new logic (e.g. Cooper, Hinings, Greenwood \& Brown, 1996; Zilber, 2006), resulting in a suppressed and a dominant logic (e.g. Reay \& Hinings, 2005; Townley, 2002), which could refer to technologies disconnected from moral assumptions or particular norms with weaker consolidated assumptions.

In the context of technology platforms, such disruption and change process is in full swing. By analyzing the disruptive impact of Uber, Laurell \& Sandstrom (2016) observed that the application would be distorting established institutions, changing "the rules of the game" (Laurell \& Sandstrom, 2016, p. 4). In fact, by directly connecting providers and consumers, peer-to-peer platforms provide an alternative to traditional mobility models and generate significant changes in the entire urban mobility segment. The impacts, however, go beyond this market and reach out to the transportation supply chain and even other production chains; thus, such impacts also affect the institutional environment by modifying rules, mental models and the perception of individuals.

Despite the relevance of such phenomenon, little is known about the real impacts of technology platforms on social, economic and institutional life. Institutional disruption alongside its mechanisms and consequences has been neglected by organizational theorists. A search in international databases using a search criterion (restricted to words in the title and keywords), the combination "institutional disruption" or just "disruption", "rupture", "change", and/or "institutional," yielded a total of 56 articles that approached institutional disruption; none of them, however, directly addressed the issue of disruption in technology or sharing platforms, such as Uber. In the databases, only one article was identified in Wiley Online Library; no article was found in the databases Web of Science, SCOPUS, SPELL, SCIELO and Sage Journals; two articles were identified in the database Emerald Publishing; and 53 in JSTOR. Most of the published articles approach institutional disruption from a public policy perspective (23); some of them address historical cultural changes (8), issues related to social causes and ethics (5), environmental issues (6), limitations that hamper economic development (5), changes in religious paradigms (1), conflicts and power relations between groups (6), philanthropy (1) and gender issues (1).

Recently, Zvolska, Palgan \& Mont (2019) pointed out that sharing platforms in general are more prone to modify institutional structures. Laurell \& Sandstrom (2016) also raised the hypothesis that Uber, in particular, would be distorting established institutions. However, these studies did not deeply investigate the phenomenon and did not present concrete and measurable evidence on it.

In Brazil, the lack of information and analysis in this field is even greater. A search carried out in some of the main Brazilian periodicals (e.g. Revista de Administração de Empresas, Revista de Administração Contemporânea, Revista de Administração da USP, Revista de Administração e Inovação, Revista Brasileira de Inovação, Revista Brasileira de Gestão e Inovação, Revista Tecnologia e Sociedade, and Organizações \& Sociedade) yielded no identification of articles using the same search criterion as previously mentioned.

In order to fill some of these gaps and open paths for the creation of new ways to observe and analyze the phenomenon, which is extremely relevant in the contemporary world, we elaborated this article, whose aim is to dive into the institutional approach from a practice 
perspective, associating it with technology platforms. From there, we elaborate and apply an analysis model constituted by a set of totally original indicators capable of mapping and measuring the extension of the ongoing phenomenon, i.e. the Uber platform.

In this context, we hypothesize that the use of the platform Uber is associated with different types of changes in the institutional logic, whether in assumptions and believes, reward and remuneration systems, organizational structure and governance, social relations or individual preferences.

The article is organized as follows. First, we present the literature review approaching institutional disruption and technology platforms considering the changes in course, and conclude the section presenting a conceptual model for analysis. Then, we present the methodological procedures, including hypothesis testing. The subsequent section presents and analyzes the results found and, finally, the last section presents the final considerations of this article.

\section{Institutional changes and technology platforms}

\subsection{Disruption and institutional change}

According to North (1990), an institution is defined by its hard-core elements, which are to be understood as the rules of the game, where moderate components sustain hard-core components (Clemens \& Cook, 1999); there is an interdependency between institutions and the systems in which they are inserted (Hira \& Hira, 2000; Peters, 2005; Pierson, 2004). Still in line with North (2006), institutions are the rules of the game-formal and informal-being also what originates them-positive or nonpositive norms-such as moral values, beliefs, habits and world perspective.

Institutions would condition the actions of individuals (Friel, 2017) as they define preferences and power in society (Powell \& DiMaggio, 1991; Thelen \& Steinmo, 1992) and provide shared meanings and cognitive frameworks that shape how humans interpret each other's behavior (Fligstein, 2001; Hall \& Taylor, 2003).

Institutional theory has evolved over the years under the dual framework of functionalism and normal science (Clegg \& Hardy, 2006, p. 30), being approached by scholars from different knowledge fields, like sociology (DiMaggio \& Powell, 1983; Roy, 1997), organizational theory (Meyer \& Rowan, 1977), political sciences (Bonchek \& Shepsle, 1996) and economics. The New Institutional Economics (NIE) considers efficient the institution that generates social welfare; being credible, reverberating and taking root in society is fundamental to the institution. Otherwise, rules and norms would be nothing but formal constructions that add no social nor economic benefits; they would generate waste and create uncertainties while hindering the establishment of a trusting environment for the creation of businesses (Coase, 1937; Simon, 1947; Williamson, 1985; North, 1990, 2006). Thus, institutional theory may be approached from different perspectives, including sociology.

The social perspective of institutional theory confirms in its neo-institutional ramifications the institutional practice approach, which examines how actors interact with constructs and resort to social and physical tools in their daily activities, which constitute the studies of practice (Lawrence \& Suddaby, 2006). Practice theorists (ex. Bourdieu, 1990; Giddens, 1984; Sztompka, 1991; Turner, 1994) acknowledge the duality between institutions and practice. Within this context, institutions are created by and-at the same time-create the action (Jarzabkowski, Matthiesen \& Van de Ven, 2009). While neo-institutionalists focus on institutional changes by attributing greater importance to agency and routine as a unit of analysis (e.g. Nelson \& Winter, 1982; Powell \& DiMaggio, 1991; Oliver, 1991; Seo \& Creed, 2002), new institutionalists concentrate their studies on transaction costs and consequences from the norms, practice theorists attach greater weight to actions, interactions and negotiations between multiple actors (Jarzabkowski et al., 2007). In such actions and interactions, actors 
initiate, reproduce and modify institutionalized practices through habits, tacit knowledge, culture, routines, motivations and emotions (Reckwitz, 2002).

The practice approach focuses on actions and interactions among actors to create, maintain and disrupt institutions (Jarzabkowski et al., 2009). In other words, the daily practices of actors produce pluralist institutions, and the interactions are full of institutional tension instead of being an exceptional or isolated phenomenon. For such flow of interactions that occur within the institutional structure, Sztompka (1991, p. 96) proposes the concept of praxis, consisting in a social process of constant mutation where organizations and their actors create and recreate institutional logics through daily practices, immersed in interactions.

Thornton, Ocasio \& Lounsbury (2012) point out that the practices and their identities are at the analytical center of institutional logics, being responsible for endogenous changes in an institutional field and providing bases for identity and collective mobilization, where the variations of the practice account for institutional transformation.

Within such context, institutional logics move via language-through theory, structure and narrative-which mutually constitutes symbolic representations of institutional logics and their material practices (Thornton et al., 2012, pp. 149-150). The narratives lead to the formulation of a vocabulary of practice and can, by linking categories to practices, bring about new institutional logics (Thornton et al., 2012, pp. 159-160).

There are several challenges in shaping new institutions, dealing with institutional inertia (Chen, 2008) and transforming existing institutions to operate in a more effective way (Amable, 2000). The problems become increasingly pressing in the context of major changes on a global scale provoked by the incessant introduction of innovation in productive systems. To understand, institutional changes have been considered a relevant matter for innovation studies (Hage \& Meeus, 2009; Hollingsworth, 2000).

According to some authors, institutional change could have a relationship with technological change, since it is characterized by path dependence and possibilities of multiple equilibria (McNicoll, 2001). Institutional change, as well as change in technology, depends on the path (the direction is constraint not only by its existing state, but also by its history) because the residues of past social actions limit the possibilities of subsequent social actions. However, change is also influenced by hopes and expectations about the future, which are not only the reflection of options immediately perceived, but are formed from information about the world and the opportunities it presents (McNicoll, 2001).

Voss (2015) argues that the institution is a byproduct of everyone's activity to adapt locally to its circumstances, which stem from complex combinations between different types of processes. Theories on institutional change typically distinguish slowly from disruptive changes. Institutional change tends to be slow and imposing, but sometimes it definitely breaks with the past or quickly responds to circumstances that change rapidly. While new institutions are created, some just disappear; others must adapt to remain sustainable (Harries, 2012).

The causes for changes are either exogenous or endogenous to the system itself. According to Harries (2012), institutional change tends to come from four main sources: (1) initiatives of institutional entrepreneurs; (2) structural overlap between participating organizations; (3) external and internal shocks from the environment related to wars, climate change or technology changes; and (4) competing institutional logics (practices, beliefs, values) that guide actions and decision-making.

In a disruptive change caused by endogenous factors, the institutional equilibrium, i.e. the compatibility between formal and informal rules, the underlying, dominant formal ideology can be changed by major technical or organizational innovations (Sauerland, 2015) within productive systems.

It occurs because over time individuals adapt their behavior to the existing set of rules, investing in learning and in the construction of successful behavioral patterns. Such process results in a patch dependency of the institutional system (Sauerland, 2015). 
For a slow and successful institutional change, new formal institutions must complement the existing informal ones and the dominant formal ideology (North, 1991). In contrast, disruptive changes are typically caused by exogenous shocks-sometimes endogenousthrough the insertion of technologies capable of drastically changing the existing paradigm (Sauerland, 2015).

In this context, institutional disruption occurs when a dominant logic is replaced by another (new beliefs, rules, norms and regulatory systems); the latter, however, coexists with other multiple institutional logics. The disruption process occurs jointly with its creation and its maintenance, where the actors try to discredit the previous institutional logical model while trying to introduce and promote the new one, in addition to creating ways to disseminate and maintain their favorite models. This institutional co-creation occurs simultaneously with disruption, as well as the development of maintenance mechanisms destined to support the institutional logic in a continuous process (Lawrence, Suddaby \& Leca, 2009).

The coexistence in the same space and at the same time of different institutional logics or institutional pluralism would explain the variations in the diffusion of institutional practices, where different logics allow viable alternatives in companies within the same industry (Lounsbury, 2007); or a process in which an institutional logic is replaced by a new logic (e.g. Cooper et al., 1996; Zilber, 2006), resulting in a suppressed and in a dominant logic (Reay \& Hinings, 2005; Townley, 2002).

For Lawrence \& Suddaby (2006), there are three basic types of institutional disruption mechanisms: (1) disconnecting sanctions and rewards; (2) disassociating moral foundations, rules and institutionalized technologies; and (3) suppressing assumptions and beliefs.

Disconnecting sanctions and rewards refers to the redefinition of established concepts and ideas through the coercive work of powerful actors that could lead to a revolutionary institutional change. This sort of institutional work occurs through the judiciary, which allows state and non-state actors to directly disconnect rewards and sanctions from practices, technologies and institutionalized rules. Actors may also disrupt institutions indirectly "by undermining the technical definitions and assumptions on which they were founded" (Lawrence \& Suddaby, 2006, p. 236).

The disassociation of moral foundations gradually disrupts the normative foundations of practices, rules or institutionalized technologies. In such process, normative foundations are more commonly disrupted by elites and powerful actors, but their activities are not directly focused on attacking those foundations (Lawrence \& Suddaby, 2006).

The suppression of assumptions and beliefs occurs when the actors remove some of the transaction costs associated with practices, technologies and prevailing rules, thus ensuring innovation and reducing costs associated with differentiation. Actors can alter assumptions and beliefs by creating an innovation that disassociates existing institutional arrangements or that gradually undermines institutions through contrary practice (Lawrence \& Suddaby, 2006).

According to Zvolska et al. (2019), actors disrupt institutions when the existing institutional order does not provide sufficient support for the accomplishment of their activities. Frequently, actors that work to create new institutions can inadvertently disassociate rules, practices and existing technologies (Lawrence \& Suddaby, 2006), thus emphasizing that institutional creation is strongly associated with institutional disruption. This could be the case of technology platforms.

\subsection{Technology platforms and institutional disruption}

Technology platforms of different types have been emerging and spreading throughout the world, hampering the creation of a concept that is concomitantly comprehensive and precise 
for each one of them. According to Gawer (2014), however, these different types of platforms share some basic properties, namely ability to coordinate agents capable of innovating and competing, possibility to generate value and benefit from economies of scope associated with supply and/or demand and presence of a modular technological architecture presenting a core and a periphery, all connected in a network. In other words, these are communities based on shared access to certain types of resources (products, services, information, etc).

Within such context, technology platforms and sharing economy are to be found. In line with Mattsson \& Barnes (2016), sharing activities have been increasing drastically and evolved from the exclusive field of information to comprise different kinds of products and resources, including peer-to-peer platforms, such as Uber (i.e. an information platform that connects globally local providers to local users for urban mobility).

A few authors have highlighted the institutional impact caused by technology platforms (Lawrence \& Suddaby; 2006). For Zvolska et al. (2019), peer-to-peer networks are prone to modify institutional structures through regulation if their objectives are aligned with existing normative socio-cognitive institutions.

An innovation supported by technological feedback mechanisms in urban sharing platforms helps replace existing behavioral models and facilitates new ways to creating trust among strangers. In the specific case of Uber and many other platforms that provide services through peer-to-peer platforms, trust is built through a system of reputation based on transparency and legitimacy (Perren \& Kozinets, 2018). Most of them invest in the creation of evaluation and classification systems, nurtured by the users individually (providers and/or customers) and useful not only to improve the system itself, but to support potential and decision-making processes of effective users.

Technology is undermining cultural and cognitive assumptions about hosting strangers at home or sharing belongings with strangers. It reduces the risks associated with the new practice and reduces transaction costs by employing technological solutions. Another assumption undermined by this sort of innovation is the typical policing role of the state; in online platforms, a new peer policing system is utilized (Zvolska et al., 2019).

When altering the value inherent in the ownership of a given good in favor of its usufruct, technology platforms involved in collaborative consumption make a direct impact on institutional logic, since value is key in an institutional logic, i.e. it is the source of legitimacy of its rules, an individual identification base for discretion, and the foundation on which its powers are built (Zvolska et al., 2019). Institutional logics are supported not only by material practices but by personal identification with an institutional value (Thornton et al., 2012). When introducing a new concept of value, platforms alter the way through which people identify with institutional values, which could lead to institutional disruption.

Platforms may also bring about disruptive effects on organizations' internal and external institutional logic when developing two-fold institutional strategies, threatening norms, behaviors, capacities, structure, among others (Jarzabkowski et al., 2007; Reckwitz, 2002).

The technology platforms also benefit from effects inherent in networks and structure their transactions through the internet and/or applications, which facilitates business between external actors and consumers while generating new business models, which would also lead to disruptive institutional effects whether by the fact that the business models do not fit in existing regulatory frameworks or by the fact that they are more dependent on organizations outside their borders, resulting in multiple institutional logics (Altman \& Tushman, 2017).

When becoming more open, their institutional logics would also be altered (Ocasio, Loewenstein \& Nigam, 2015), since platforms need to establish trust with external parties (Altman \& Tushman, 2017); in many cases, the external party is a competitor, which leads to competition (Brandenburger \& Nalebuff, 1996; Gnyawali \& Park, 2011). 
As it becomes more open, the platforms provides information on interfaces and launch of products, allowing external participants to develop complementary (Altman \& Tushman, 2017; Wry, Cobb \& Aldrich, 2013) or substitute products and services, which is not common for organizations that do not operate through platforms of collaborative consumption. The very nature of the product promotes the weakening of consolidated assumptions, whichwhen changing the value of an asset-has a direct impact on the institutional logic (Reay \& Hinings, 2005; Townley, 2002; Zvolska et al., 2019), changing the way through which actors identify with institutional value (Thornton et al., 2012) and leading to institutional disruption (Glynn \& Lounsbury, 2005; Suddaby \& Greenwood, 2005; Cooper et al., 1996; Zilber, 2006).

By adopting a model of independent providers (Schor \& Attwood-charles, 2017), the platforms introduce differentiated rewarding and evaluation systems in relation to employed workers (Andersson, Hjalmarsson \& Avital, 2013; Avital et al., 2014) and radically change work relations (for further information on this matter, see Codagnone, Abadie \& Biagi, 2016; Graham \& Woodcock, 2018; Manyika, Lund, Bughin, Robinson, Mischke \& Mahajan, 2016; Todolí-Signes, 2017; and Vaclavik \& Pithan, 2018). In addition, many platforms utilize metrics focused on the interaction among users and depend on ratings and reputation data to reduce risk and increase trust (Avital et al., 2014). Thus, they promote institutional disruption by managing multiple interactions (Jarzabkowski et al., 2007; Reckwitz, 2002) and affecting the entire value chain (Altman \& Tushman, 2017).

\subsection{Analysis model}

Based on the considerations and analyses carried out herein, we present the analysis model utilized in this research (Figure 1).

In the proposed model, peer-to-peer platforms gather the institutional disruption mechanisms pointed out by Lawrence \& Suddaby (2006), which would trigger changes in the institutional order. Regarding the disconnection of sanctions and rewards, these platforms would change the institutional structures through regulatory activities directly disconnecting rewards and sanctions from practices, technologies and institutionalized rules (Zvolska et al., 2019). It would affect not only consumer attitudes and behavior, but it would also challenge deeply rooted assumptions and social patterns (Zervas et al., 2017) through the insertion of a new evaluation system based on reputation (Avital et al., 2014), a new remuneration logic, based on variable income (Andersson et al., 2013; Lanier, 2013), and autonomy and work flexibility focused on individual efforts. In this new individualityoriented paradigm, old problems stemming from teamwork and bureaucratic structures disappear, but, at the same time, new issues emerge related to the sense of labor (Vaclavik \& Pithan, 2018), future of work (Codagnone et al., 2016), fair working conditions (Graham \& Woodcock, 2018) and especially gig economy (Manyika et al., 2016; Todolí-Signes, 2017).

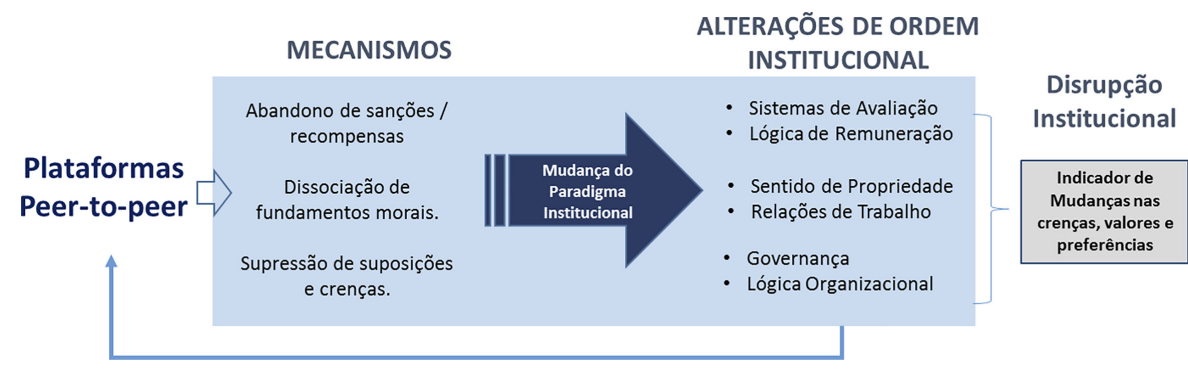

Figure 1. Analytical model 
The dissociation of moral foundations occurs through practices that promote sharing with strangers and second-hand consumption aiming at sustainability (Zvolska et al., 2019), changing the value inherent in ownership through the shift to the usufruct of the good and sharing instead of owning (Botsman \& Rogers, 2010). In this scenario, work relations are no longer based on fixed salaries and subordination to direct supervision (Kittur et al., 2013).

The suppression of assumptions and beliefs occurs with the disruption of existing institutional configurations. The practice of giving feedback to peers in online platforms is gradually changing assumptions about doing business with strangers, new cognitive institutions are being created and normalized, and people are gradually starting to accept these practices (Zvolska et al., 2019). The platforms reduce transaction costs through an open management structure based on transparency, trust and legitimacy (Perren \& Kozinets, 2018), with multiple interactions managed by corporate governance (Bresnahan \& Greenstein, 2014; Andersson et al., 2013; Avital et al., 2014) and organizational relations based on the intermediation between provider and producer (Altman \& Tushman, 2017; Perren \& Kozinets, 2018; Sundararajan, 2016).

Such change in behavior challenges deeply rooted assumptions and social patterns (Zervas et al., 2017; Reay \& Hinings, 2005; Townley, 2002; Zvolska et al., 2019). In order to measure the impact of these changes, we will present in the upcoming section-along with the methodological procedures-the indicator "changes in institutional beliefs, perceptions, and preferences."

\section{Method}

The field research, based on probability and stratified sampling, was composed of two samples of users (drivers and passenger) from the application Uber in the city of Belo Horizonte, Brazil. We chose the city of Belo Horizonte to carry out the research because, in addition to being a large urban center, it was one of the first cities to allow the operation of the app in September 2014.

Considering the confidentiality policy of the application, we considered as research universe the adult population (18 to 65 years of age) in the city, estimated at 1,628,469 (IBGE, 2019). To calculate the sample size $(n)$ (Cochran, 1977), we considered a $95 \%$ confidence interval with a $5 \%$ margin of error, resulting in a total of 384 customers and 384 drivers. Taking into account the possible existence of missing data and outliers, the sample size was expanded to 843 users (446 consumers and 397 drivers), stratified (Malhotra, 2012) by gender (consumers) and census tracts of the city (32 tracts). Each of the tracts was randomly drawn.

Between May and August 2019, people who traveled near schools, malls and shopping centers withing the census tracts were interviewed. In the case of drivers, due to confidentiality issues of the application, the approach occurred in places where they usually wait to provide the service, e.g. queues at airports, bus stations and malls, within the boundaries of the census tracts. After excluding two interviews, in accordance with the criterion provided by the European Social Survey (ESS as cited in Sambiase, Teixeira, Bilskyb, de Araujo \& De Domenicoa, 2014), the sample totaled 841 users (444 customers and 397 drivers).

The bibliographic research carried out herein enabled the elaboration of a data collection instrument consisting of structured questions-resulting in 14 questions elaborated to cover the research universe-stemming from the theoretical model and in line with theoretical propositions, whose data provided were used to support the hypothesis testing of our research.

The free and informed consent was established through registration on the virtual platform used to operationalize the study. Such consent was informed in a dialog box at the beginning of the process of filling in the data by users. 
The operationalization of the data collection was supported by Ápice-a junior company from the university PUC Minas. The data collection was carried out by a team composed of experienced professionals and constituted by four researchers, three coordinatorssupervisors and 55 technicians. The team received specific training to operationalize the data collection and the critical analysis of the data.

The team approached individuals in places selected by stratification, ensuring the randomness of the sample. They were asked if they were users of the Uber platform; in case of a positive response, they would be invited to take part in the research.

The elaboration of the instrument and its refinement constitute both spheres that must be considered to validate a content (Hoppen et al., 1996). To validate the content, question wording was based on the theoretical propositions and hypotheses stemming from literature review on platforms and institutional changes. This sort of validation ensures that the indicators utilized consistently represent the phenomenon under evaluation.

Subsequently, we did a pre-testing to administrate the data collection instrument. In the pre-testing phase, also known as pilot testing, we considered the guidelines proposed by Gil (1991), who claims that the following aspects must be taken into consideration: clarity and precision of terms, number of questions, form of questions, order of questions and introduction.

The pre-testing was carried out in two stages. First, the questionnaires were elaborated and subsequently printed, and 40 Uber users were approached to answer the questions. Considering the anxiety presented by most users, a dynamic online questionnaire was developed in order to improve the dynamics of the interview.

The second pre-testing, which relied on structured questions available at an online and dynamic platform and was operationalized through tablets, was accomplished with 25 interviewees. The number of interviewees met the minimum criterion of 15 interviews, as suggested by Malhotra (2012) in the pre-testing. This procedure was important to evaluate the elaborated electronic platform, public's acceptance to join the study and to assess respondents' understanding of the wordings.

A number of factors were taken into account when creating the questionnaire, following the guidelines proposed by Perrien, Chéron \& Zins (1984): We made use of a high number of options for closed-ended questions to cover all possible answers; only questions strictly related to the research issue were applied, we considered the implications of the questions in the procedures of data tabulation and analysis; and the questions were formulated to enable a single interpretation consisting in one single idea, reassuring the respondents the confidentiality of personal data.

To verify the quality level of the data collection, the following procedures were carried out: (1) auditing the transcriptions of the electronic research forms; (2) phone calls made to interviewees to confirm the provided information and (3) evaluation of the complete filling of the research forms according to the registration of the electronic research system.

According to Maxwell (apud Bickman \& Rog, 1997), in the data analysis procedure, it is important to observe if all questions were correctly answered, if the answers indicate any sort of difficulty to understand the question, and how the questionnaire was completed. As data analysis technique, the multidimensional analysis was used (Hair et al., 1994), where the researcher simultaneously analyzes more than two variables either to summarize findings or to carry out a deeper analysis. During this process, a few categories of analysis were established based on literature, thus facilitating data interpretation and codification (Eisenhardt, 1989).

The data collected through the questionnaire were grouped according to the categories of analysis. The indicator was created based on the structured questions, with the support from Likert scale. The test statistic considered in hypothesis testing is based on a student's tdistribution, since the mean and standard deviation of the population is known; a normal distribution is desired.
Institutional disruption and technology platforms

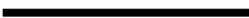


Podsakoff, MacKenzie \& Lee (2003) argue that the occurrence of common method bias is more frequent when the same type of scale is utilized, with the same number of answer options, and cross-sectional analysis, i.e. at a specific point in time. To verify the occurrence of common method bias (Podsakoff et al., 2003), Harman's single factor test was performed, which is a widely employed technique to evaluate common method bias (Podsakoff et al., 2003). For this purpose, an exploratory factor analysis was carried out utilizing all variables that make up the study, creating one single factor. When the variance explained in factor analysis is below $50 \%$, the common method utilized in data collection is not a concern (Podsakoff et al., 2003).

Using Statistical Product and Service Solutions (SPSS) V.25, we adopted the component extraction method and unrotated factor solution, as suggested by Podsakoff et al. (2003). In the present research, the outcome of the exploratory factor analysis indicated an explained variance of $29.17 \%$ through Harman's single factor test, no significant evidence on common method bias was found.

To verify the reliability of the scales, the Cronbach's alpha $(\alpha)$ was verified, whose purpose is to indicate the percentage of the variance of measures that are free from random errors (Malhotra, 2012). Landis \& Koch (1977) point out that values above 0.61 are acceptable; in this research, the Cronbach's alpha was 0.71 , which guarantees the internal consistency of the utilized scales.

The existence of missing data, suspicious survey response patterns, outliers (Hair, Hult, Ringle \& Sarstedt, 2014) and survey straight-lining-which can be an indication of acquiescence bias (Podsakoff et al., 2003)-was verified. To detect outliers (Hair et al., 2009), the univariate outlier detection indicates values above four standard deviations as a reference to characterize an atypical observation.

To verify the impacts created by platforms from a user perspective, who suggest ongoing institutional changes, the indicator changes in institutional beliefs, perceptions and preferences was developed and operationalized through Likert scale questions applied to application users. Through a single questionnaire, users would be able to describe changes occurring after joining the platform in comparison to their perceptions before getting to know Uber. The questions were grouped in six key variables, namely importance of ownership, work relations, remuneration logic, governance of these organizations, reward and sanction systems, and organizational structure. They were developed based on the concepts established by Lawrence \& Suddaby (2006), Voss (2015), Harries (2012), and Zvolska et al. (2019) associated with the following Likert scale questions (Table 1 and Eqn 1).

Questions P3, P6, P7, P9, P12 and P13 were applied only to drivers; the other questions, which do not require previous experience as drivers, were applied to both samples of users, allowing the comparison between the two categories to evaluate alterations in the perception of institutional changes between drivers and users.

The indicator presents the perceived differences before and after the usage of the platform by users and was created based on Likert scale data (P1 to P14), grouped into categories (I1 to I6) through the average and converted into indexes that range from -1 to 1 . Eqn (1) demonstrates the calculation of the indicator.

$$
\text { ImpInst }=\frac{(\mathrm{I} 1+\mathrm{I} 2+\mathrm{I} 3+\mathrm{I} 4+\mathrm{I} 5+\mathrm{I} 6)}{6}
$$

where:

ImpInst $=$ Indicator for changes in institutional beliefs, perceptions, and preferences.

I1, I2, I3 = Likert scale questions Average.

$n=$ Sample size. 


\begin{tabular}{|c|c|c|c|}
\hline Mechanisms & Categories & Questions & \\
\hline \multirow[t]{2}{*}{$\begin{array}{l}\text { Abandonment of traditional } \\
\text { sanctions / rewards }\end{array}$} & $\begin{array}{l}\text { I1. Rewards and } \\
\text { sanctions systems }\end{array}$ & $\begin{array}{l}\text { P1. The scoring / reputation system of the } \\
\text { platform's users is very different from the } \\
\text { recognition systems of traditional } \\
\text { organizations } \\
\text { P2. The scoring system for choosing drivers is } \\
\text { very relevant when using the application }\end{array}$ & $\begin{array}{r}\text { technology } \\
\text { platforms }\end{array}$ \\
\hline & $\begin{array}{l}\text { I2. Remuneration } \\
\text { logic }\end{array}$ & $\begin{array}{l}\text { P3. The platform's remuneration logic is more } \\
\text { financially advantageous than through } \\
\text { conventional employment } \\
\text { P4. Uber represents an easy-to-access } \\
\text { alternative for earning money }\end{array}$ & \\
\hline $\begin{array}{l}\text { Dissociation of moral foundations, } \\
\text { rules and institutionalized } \\
\text { technologies }\end{array}$ & $\begin{array}{l}\text { I3. Sense of } \\
\text { ownership } \\
\text { I4. Employment } \\
\text { relations }\end{array}$ & $\begin{array}{l}\text { P5. I Prefer to use Uber instead of driving in } \\
\text { my own vehicle } \\
\text { P6. I don't feel like an employee, but I feel like a } \\
\text { platform partner } \\
\text { P7. It is better to have impersonal } \\
\text { relationships with the platform's } \\
\text { administrators than to subject oneself to the } \\
\text { wishes and whims of a boss } \\
\text { P8. Uber has greatly changed the relationship } \\
\text { between company, employee and service } \\
\text { provider }\end{array}$ & \\
\hline \multirow[t]{3}{*}{$\begin{array}{l}\text { Suppression of assumptions and } \\
\text { beliefs }\end{array}$} & I5. Governance & $\begin{array}{l}\text { P9. Performance evaluation systems (eg, } \\
\text { reputation) are very different from those I } \\
\text { knew in traditional organizations } \\
\text { P10. It is better to have a flexible work time at } \\
\text { Uber than to submit to a rigid 8-h work at a } \\
\text { company }\end{array}$ & \\
\hline & $\begin{array}{l}\text { I6. Logic / } \\
\text { organizational } \\
\text { structure }\end{array}$ & $\begin{array}{l}\text { P11. Uber has a very different operating logic } \\
\text { from traditional companies } \\
\text { P12. Working with Uber is very different from } \\
\text { working with traditional transport services } \\
\text { (eg taxi) } \\
\text { P13. At the same time that I provide service as } \\
\text { a driver, I also feel that I am a client of the } \\
\text { platform }\end{array}$ & \\
\hline & & $\begin{array}{l}\text { P14. With Uber I feel like I can make a living as } \\
\text { a driver anywhere, including abroad }\end{array}$ & $\begin{array}{r}\text { Table 1. } \\
\text { Institutional disruption } \\
\text { and sharing platforms }\end{array}$ \\
\hline
\end{tabular}

$$
\text { User } K, k=1,2, \ldots ., p
$$

If the indicator is greater than 0 , it will be proved that the platforms affect users' perceptions on factor that suggest ongoing institutional changes; the higher the indicator, the greater the impact on institutional logic. Based on data provided by the indicator, it was possible to carry out the t-test, which corresponds to the univariate hypothesis testing and is utilized to compare means when the standard deviation is unknown (Malhotra, 2012).

\subsection{T-test}

HO. The indicator for changes in institutional beliefs, perceptions, and preferences presents values equal to zero $(p>0.05)$. 


\section{REGE}

\section{Results and analysis}

Figure 2 presents the results of the indicator for institutional change elements that comprise the perceived differences in the sense of ownership, work relations, reward and sanction systems, remuneration logic, governance, and organizational structure between platforms and traditional organizations.

The data point to the confirmation of the perceived differences in all items, indicating that the elements of the rules of the game presented representative changes in users' perceptions, where changes in reward and sanction systems, governance and organizational structure are emphasized. The higher the value, the greater the changes perceived by users.

The sample of drivers showed a higher rate of perceptions of changes in the institutional environment when compared to the sample of passengers in all categories, except for the reward and sanction systems, where the perception of passengers' institutional change is higher.

In order to assess the significance of the data, hypothesis testing was carried out (Table 2) to verify if the platforms affect the perception of users about factors that suggest ongoing institutional changes.

It is observed that $p$-value is less than 0.05 in all variables related to institutional aspects, thus rejecting the null hypothesis. It is possible to assume, therefore, that mobility platforms change the need of ownership (migration from vehicle ownership to service usage), change the nature of work relations, promote changes in reward and sanction systems and in remuneration logic, in addition to changing the nature of governance and organizational structure.

Through the equation of the indicator for changes in institutional beliefs, perceptions and preferences, the following values were obtained: 0.48 for the complete sample (drivers and passengers); 0.55 for the sample composed only of drivers and 0.42 for the sample composed

Figure 2.

Changes in the perception of institutional environment

\section{REGRAS DO JOGO}

I1. Sistemas de Recompensas e Sanções:

12. Lógica de Remuneração

13. Sentido de Propriedade

14. Relações de Trabalho

16. Lógica/Estrutura Organizacional:

Somente Passageiros

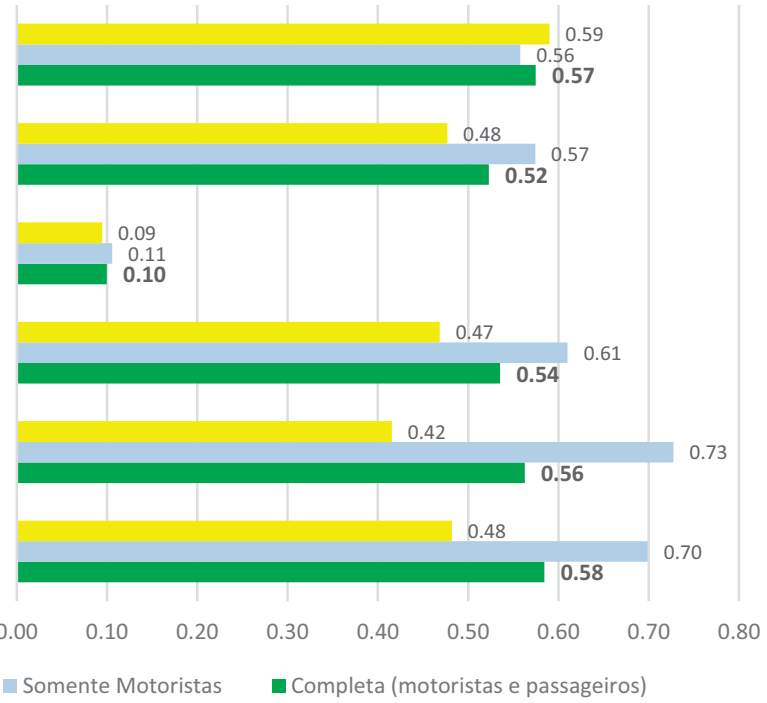

Source(s): Research data 
only by passengers, which indicates that, on a scale of -1 to 1 , the changes in the rules of the game (Laurell \& Sandstrom, 2016) promoted by platforms are significant.

When liken the sample of passengers to the sample of drivers, it is observed (Table 3 ) that the perception of drivers regarding changes in governance is $43 \%$ higher compared to passengers, followed by the perception of changes in organizational logic/structure $(31 \%$ higher), work relations ( $23 \%$ higher), remuneration logic (17\% higher), sense of ownership (11\% higher), and reward and sanction systems $(6 \%)$ higher.

The indicator changes in institutional beliefs, perceptions and preferences presented positive changes of about $48 \%$ in both samples surveyed, which indicates institutional disruption (Jarzabkowski et al., 2007, 2009) through the disconnection of consolidated assumptions, the disassociation of moral foundations, rules and institutionalized technologies, and the suppression of assumptions and beliefs (Cooper et al., 1996; Zilber, 2006; Reay \& Hinings, 2005; Townley, 2002; Lawrencee \& Suddaby, 2006), which occurs through changes in the sense of ownership $(10.0 \%)$, work relations $(53.5 \%)$, reward and sanction systems $(57.5 \%)$, remuneration logic $(52.3 \%)$, governance $(56.3 \%)$ and organizational structure $(58.4 \%)$.

Regarding the suppression of traditional sanctions and rewards (Zvolska et al., 2019), it is observed that Uber has affected consumption attitudes and behaviors while challenging deeply rooted assumptions and social patterns (Zervas et al., 2017); 63\% of users agree that Uber's reward system based on scores and reputation is very different from those of traditional companies, and $76 \%$ of users affirm that the reward system is relevant and useful

\begin{tabular}{|c|c|c|c|c|c|c|c|}
\hline \multirow[b]{2}{*}{ Mecanism } & \multirow[b]{2}{*}{ Category } & \multirow[b]{2}{*}{$t$} & \multirow[b]{2}{*}{$\mathrm{df}$} & \multicolumn{2}{|c|}{ Test value $=0$} & \multicolumn{2}{|c|}{$\begin{array}{l}95 \% \text { confidence } \\
\text { interval of } \\
\text { difference }\end{array}$} \\
\hline & & & & extremity & difference & Lower & Upper \\
\hline \multirow[t]{2}{*}{$\begin{array}{l}\text { Abandonment of } \\
\text { traditional sanctions }\end{array}$} & $\begin{array}{l}\text { I1. Rewards and } \\
\text { sanctions } \\
\text { systems }\end{array}$ & 33,614 & 840 & 0.000 & 0.57491 & 0.5413 & 0.6085 \\
\hline & $\begin{array}{l}\text { I2. Remuneration } \\
\text { logic }\end{array}$ & 51,616 & 840 & 0.000 & 0.52289 & 0.5030 & 0.5428 \\
\hline \multirow{4}{*}{$\begin{array}{l}\text { Dissociation of moral } \\
\text { foundations, rules and } \\
\text { institutionalized } \\
\text { technologies } \\
\text { Suppression of } \\
\text { assumptions and beliefs }\end{array}$} & $\begin{array}{l}\text { I3. Sense of } \\
\text { ownership }\end{array}$ & 4,089 & 840 & 0.000 & 0.09988 & 0.0519 & 0.1478 \\
\hline & $\begin{array}{l}\text { I4. Employment } \\
\text { relations }\end{array}$ & 42,189 & 840 & 0.000 & 0.53537 & 0.5105 & 0.5603 \\
\hline & I5. Governance & 42,776 & 840 & 0.000 & 0.56272 & 0.5369 & 0.5885 \\
\hline & $\begin{array}{l}\text { I6. Logic / } \\
\text { organizational } \\
\text { structure }\end{array}$ & 45,435 & 840 & 0.000 & 0.58442 & 0.5592 & 0.6097 \\
\hline
\end{tabular}

Source(s): Search data
Institutional disruption and technology platforms

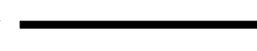

\begin{tabular}{|c|c|c|c|c|}
\hline \multicolumn{4}{|l|}{ Source(s): Search data } & \multirow[t]{2}{*}{ preferences } \\
\hline Category & Drivers & Passengers & Delta \% & \\
\hline I6. Logic/organizational structure & 0.70 & 0.48 & -31 & \multirow{7}{*}{$\begin{array}{r}\text { Table } 3 . \\
\text { Comparative changes } \\
\text { in institutional beliefs, } \\
\text { perceptions and } \\
\text { preferences }\end{array}$} \\
\hline I5. Governance & 0.73 & 0.42 & -43 & \\
\hline I4. Employment relations & 0.61 & 0.47 & -23 & \\
\hline I3. Sense of ownership & 0.11 & 0.09 & -11 & \\
\hline I2. Remuneration logic & 0.57 & 0.48 & -17 & \\
\hline I1. Rewards and sanctions systems & 0.56 & 0.59 & 6 & \\
\hline Source(s): Search data & & & & \\
\hline
\end{tabular}


to choose drivers. Considering the remuneration logic, $60 \%$ of the interviewees affirm that Uber provides a more attractive remuneration system than those of gainful employment, and $95 \%$ consider that Uber allows for a new form of work and remuneration.

The changes promoted through the dissociation of moral foundations, rules and institutionalized technologies (Lawrence \& Suddaby, 2006; Harries, 2012; Voss 2015) indicate that the practice of sharing with strangers and consumption of second-hand goods (Zvolska et al., 2019) has been widely utilized by users. $53 \%$ of respondents affirmed to prefer Uber services than driving a private car, which reduces the propensity of owning a car and the use of traditional mobility services (Martin \& Shaheen, 2011; Meyer \& Shaheen, 2017). With respect to work relations, $85 \%$ of the interviewees feel like partners instead of employees of the platform; $89 \%$ affirm to prefer an impersonal relationship with the administrators of the platform and $71 \%$ consider that Uber has changed a lot the relationship between employee and service provider.

Different social roles, which where until then quite clear and defined in the economic world, began to blend in the context of mobility applications. Uber suppressed previous, deeply rooted assumptions and beliefs by introducing a new form of governance and organizational structure based on a system where trust is created through reputation based on transparency, trust and legitimacy (Perren \& Kozinets, 2018), thus replacing traditional behavioral models. In our survey, $84 \%$ of respondents affirmed that the evaluation and performance systems are different from those of traditional organizations, and $69 \%$ consider the flexible working schedule provided by the platform more attractive than fixed working hours.

The applications have been changing the way people make a living, how they position themselves on the labor market, how they adjust to new technologies and organizational models and how they perceive the institutional environment around them. Considering that $68 \%$ of users consider Uber's operation logic very different from traditional companies, $87 \%$ had to undergo major changes to work for the platform, $91 \%$ of drivers feel like customers and, at the same time, service providers, and $83 \%$ consider that it is possible to make a living anywhere as a driver, including abroad.

As previously observed, traditional norms, habits, consumption and beliefs (Jarzabkowski et al., 2007; Reckwitz, 2002) gave way to new values, beliefs, habits and practices (Glynn \& Lounsbury, 2005; Suddaby \& Greenwood, 2005; Cooper et al., 1996; Zilber, 2006), disrupting the institutional basis.

Disruptive changes caused by mobility platforms are drastically changing the current paradigm (Sauerland, 2015)-e.g. the ownership value, which has been replaced by the usufruct of a good. Another example are previous rules in the entrepreneurial environment, where an individual must be subordinate to a boss and employed, which are being replaced by outsourced employees or platform's partner, who are provided with a more flexible working schedule. The same way, the relations become more open and flexible, since they are inserted in an environment of constant change, where agents always pursue a balance between the number of users/consumers and users/drivers, the latter are also considered clients and producers/partners of the platform.

Along with new forms of governance, new organizational structures, management models and new state regulations emerge. These changes and transformations coexist with other previously dominant institutional logics, leading to institutional disruption (Lawrence et al., 2009), which is in line with Schumpeter's (1942) assumption on the disruptive nature of innovation, i.e. capable of launching a new socio-economic system.

\section{Final considerations}

The research findings corroborate the propositions of Lawrence \& Suddaby (2006) about the mechanisms of institutional disruption, whether by disconnecting traditional rewards and 
sanctions (e.g. rewards and sanctions by scores); disassociating moral foundations, rules and institutionalized technologies (e.g. alteration in the work relation between employee and service provider) or undermining assumptions and beliefs (e.g. changes in governance and organizational logic).

In this sense, the article helps to fill the gap initially pointed out by Laurell \& Sandstrom (2016) by verifying and confirming the hypothesis that Uber is associated with different types of changes in institutional logic; and concomitantly addressing the research by Zvolska et al. (2019) when indicating that sharing platforms are prone to modify institutional structures. The findings also corroborate studies on institutional disruption, which goes beyond the field of public policies, as pointed out at the beginning of this article.

The perceptions of drivers of ongoing institutional changes $(0.55)$ were higher compared to passengers' perceptions (0.42), which is mainly influenced by the perception of changes in governance, organizational logic/structure and work relations, reinforcing the understanding that practices and their identities are at the analytical center of institutional logics (Thornton et al., 2012). Since drivers are more immersed in actions, interactions and negotiations (Jarzabkowski et al., 2007) through the platform, they would be more prone to reproduce and modify institutionalized practices by means of habits, tacit knowledge, culture, routines, motivations and emotions (Reckwitz, 2002).

Thornton et al. (2012) argue that practices and their identities are at the analytical center of institutional logics, account for endogenous changes in an institutional field, and provide bases for identity and collective mobilization, where the variations in practice account for institutional transformation.

Within such context, institutional logics move via language-through theory, structure and narrative-which mutually constitutes symbolic representations of institutional logics and their material practices (Thornton et al., 2012, pp. 149-150). The narratives lead to the formulation of a vocabulary of practice and can, by linking categories to practices, bring about new institutional logics (Thornton et al., 2012, pp. 159-160).

The multiple changes that have taken place across platforms-specially Uber-indicate the promotion of a new type of disruption-institutional-by introducing not only a wide variety of new services, but also new ways of doing old things, new beliefs, habits, rules, giving rise to new institutional devices (Villaschi Filho, 2005, p. 68).

In this scenario, amid the impacts presented herein, public policymakers should reconsider their regulatory practices taking into account individual preferences and tacit responses of economic agents to the rules of the game. It means that the action logics of individuals and organizations are being deeply modified.

In the specific case of Uber, many users are no longer utilizing private cars. This has strong repercussions in social and economic life. A new type of economy is emerging, in which the interest of the user/consumer is the usufruct of a good, not its ownership. The access-based consumption-unlike ownership- eleases the individual from any sort of economic, social or emotional obligations related to owning a good (Botsman \& Rogers, 2010), affecting consumption attitudes and behaviors and challenging deeply rooted assumptions and patterns (Zervas et al., 2017).

When changing the importance inherent in the ownership of a good and favoring its usufruct, technology platforms of sharing economy cause direct impacts on institutional logic (Zvolska et al., 2019) because many individuals start to favor and prefer the usufruct of a good instead of owning it. By offering users usage benefits at lower costs, such use starts being an alternative to traditional ownership (Botsman \& Rogers, 2010), which indicates a disruption with private property-one of the foundations of the capitalist world-and suggests the emergence of elements that could eventually trigger a new type of "techno-economic paradigm."

Thus, impacts arising from a disruptive innovation, i.e. in the case of digital mobility platforms, promote effects at the macro level, which modifies institutional bases 
(Suddaby \& Greenwood, 2005; Lawrence et al., 2009; Altman \& Tushman, 2017; Laurell \& Sandstrom, 2016, Thornton et al., 2012; Zvolska et al., 2019) and indicates a creative disruption process in the long term (Schumpeter, 1942).

This study presents a few limitations, such as the absence of a qualitative research approach that could enable the establishment of deeper explanation on the impacts caused by applications, including those of institutional nature, which could lead to greater developments in the institutional logic, as well as in the quality of life and utilization of resources among users.

We suggest, as research agenda, that the theoretical model, as well as the hypothesis, become the focus of new empirical tests and theoretical-conceptual analysis. The accomplishment of cross-national studies that evaluate the impacts of urban mobility platforms, in addition to changes in institutional logic, can increase the generalizability of results.

The data demonstrated herein, referring to the city of Belo Horizonte, indicate the strength of the theoretical model and the potential use of the indicators created by us, allowing for adjustments and improvements according to the different metropolitan realities.

\section{References}

Altman, E.J., \& Tushman, M.L. (2017). Platforms, open / user innovation, and Ecosystems : A strategic leadership perspective platforms. Working Paper 17-076. Boston: Harvard Business School Press.

Amable, B. (2000). Institutional complementarity and diversity of social systems of innovation and production. Review of International Political Economy, 7, 645-687.

Andersson, M., Hjalmarsson, A. and Avital, M. (2013). Peer-to-Peer service sharing platforms: Driving share and share alike on a mass-scale, Proceedings of the 34th International Conference on Information Systems (ICIS), Milan, Italy.

Avital, M., Andersson, M., Nickerson, J., Sundararajan, A., Van Alstyne, M. \& Verhoeven, D. (2014). The collaborative economy: A disruptive innovation or much ado about nothing?. Proceedings of the 35th International Conference on Information Systems (ICIS), Auckland, New Zealand.

Bickman, L., \& Rog, D.J. (1997). Handbook of applied social research methods. Thousand Oaks: Sage, 580.

Bonchek, M. S., \& Shepsle, K. A. (1996). Analyzing politics: Rationality, behavior and instititutions. NewYork, NY:W.W. Norton \& Co.

Botsman, R., \& Rogers, R. (2010). Beyond zipcar: Collaborative consumption. Harvard Business Review, 88(October), 30.

Bourdieu, P. (1990). The logic of practice. Cambridge: Polity Press.

Brandenburger, A., \& Nalebuff, B. (1996). Co-opetition (1st ed.). New York: Currency/Doubleday.

Bresnahan, T., \& Greenstein, S. (2014). Mobile computing: The next platform rivalry. American Economic Review, 104(5), 475-480.

Chen, L., 2008. Institutional inertia, adjustment, and change: Japan as a case of a coordinated market economy. The Review of International Political Economy, 15, 460-479.

Clegg, S.R., \& Hardy, C. (2006). Handbook de estudos organizacionais: Modelos de análise e novas questões em estudos organizacionais (3rd ed.). São Paulo: Atlas.

Clemens, E.S., \& Cook, J.M. (1999). Politics and institutionalism: Explaining durability and change. The Annual Review of Sociology. 25, 441-466.

Coase, R. (1937). The nature of the firm. Economica, 4(16), new series, 386-405. doi: 10.2307/2626876.

Cochran, W.G. (1977). Sampling Techniques (3rd ed.). New York: Wiley. 
Codagnone, C., Abadie, F., \& Biagi, F. (2016). The future of work in the 'sharing economy': Market efficiency and equitable opportunities or unfair precarisation?, JRC Science for Policy Report, EUR 27912, 1, 1-100. doi: 10.2791/431485.

Cooper D.J., Hinings B., Greenwood R., \& Brown, J.L. (1996). Sedimentation and transformation in organizational change: The case of Canadian law firms. Organization Studies, 17, 623-647.

DiMaggio, P.J., \& Powell, W.W. (1983). The iron cage revisited: Institutional isomorphism and collective rationality in organizational fields. American Sociological Review, 48, 147-160.

Eisenhardt, K.M. (1989). Building theories from case study research. Academy of Management Review: Standford University, 14, 532-550.

Fligstein, N. (2001). Social skill and the theory of fields. Sociological Theory, 19(2), 105-125.

Friedland, R. \& Alford, R.R. (1991). Bringing society back in: Symbols, practices, and institutional contradictions. Powell, W.W. \& DiMaggio, P.J. (Eds.), The new institutionalism in organizational analysis, Chicago: University of Chicago Press, 232-263.

Friel, D. (2017). Understanding institutions: Different paradigms, different conclusions. Revista de Administração, 52, 212-214.

Gawer, A. (2014). Bridging differing perspectives on technological platforms: Toward an integrative framework. Research Policy, 43, 1239-1249.

Giddens, A. (1984). The constitution of society. Cambridge: Polity Press.

Gil, A.C. (1991). Como elaborar projetos de pesquisa (3a ed.). 159. São Paulo: Atlas.

Glynn, M., \& Lounsbury, M. (2005). From the critics"corner: Logic blending, discursive change and authenticity in a cultural production system. Journal of Management Studies, 42(5), 1031-1055.

Gnyawali, D.R., \& Park, B. (2011). Co-opetition between giants: Collaboration with competitors for technological innovation. Research Policy, 40, 650-663.

Graham, M., \& Woodcock, J. (2018). Towards a fairer platform economy: Introducing the fairwork foundation. Alternate Routes, 29, 242-253.

Hage, J., \& Meeus, M. (2009). Innovation, science, and institutional change: A research handbook. New York, NY: Oxford University Press.

Hair, J.F., Black, W.C., Babin, B.J., \& Anderson, R.E. (1994). Multivariate data analysis. New Jersey, NJ: Prentice Hall.

Hair, J.F., Black, W.C., Babin, B.J., Anderson, R.E. \& Tatham, R.L. (2009). Análise multivariada de dados (6 ed.). Porto Alegre: Bookman Editora.

Hair, J.F., Hult, G.T.M., Ringle, C. \& Sarstedt, M. (2014). A primer on partial least squares structural equation modeling (PLS-SEM). Thousand Oaks, CA: Sage Publications.

Hall, P.A., \& Taylor, R.C.R. (2003). As três versões do neo-institucionalismo, São Paulo: Lua Nova.

Harries, S. (2012). Innovation and change: Ideas, networks and communities. in Stephen Harries, (Ed.). Chandos Information Professional Series, Records Management and Knowledge Mobilisation, Chandos Publishing, 115-141.

Hira, A., \& Hira, R. (2000). The new institutionalism: Contradictory notions of change. The American Journal of Economics and Sociology, 59, 267-282.

Hollingsworth, J.R., (2000). Doing institutional analysis: Implications for the study of innovations. Review of International Political Economy. 7, 595-644.

Hoppen, N., Lapointe, L., \& Moreau, E. (1996). Um guia para a avaliação de artigos de pesquisas em sistemas de informações (7a ed.). Porto Alegre: RS, 2(2).

IBGE - INSTITUTO BRASILEIRO DE GEOGRAFIA E ESTATÍSTICA (2019). Panorama Minas Gerais. available at: https://cidades.ibge.gov.br/brasil/mg (accessed 22 June 2019).

Jarzabkowski, P., Balogun, J., \& Seidl, D. (2007). "Strategizing: The challenges of a practice perspective“. Human Relations, 60(1), 5-27. 
Jarzabkowski, P., Matthiesen, J., \& Van de Vem, A. (2009). Doing which work? A practice approach to institutional pluralismo. In Lawrence, T., Leca, B., \& Suddaby, R. (Eds) Institutional Work: Actors and Agency in Institutional Studies of Organizations. Cambridge: Cambridge University Press.

Kittur, A., Nickerson, J.V., Bernstein, M S., Gerber, E.M., Shaw, A.D., Zimmerman, J., Lease, M., \& Horton, J.J. (2013). The future of crowd work. CSCW 2013: Proceedings of the ACM Conference on Computer-Supported Cooperative Work. New York: ACM Press.

Landis, J., \& Koch, G. (1977). The measurement of observer agreement for categorical data. Biometrics, 33(1), 159-74.

Lanier, J. (2013). Who owns the future? New York, NY: Simon \& Schuster.

Laurell, C., \& Sandstrom, C., 2016. Analysing Uber in social media - disruptive tech- $€$ nology or institutional disruption?, International Journal of Innovation Management. 20(5), 1-19.

Lawrence, T.B., \& Suddaby, R. (2006). Institutions and institutional work. In: Clegg, S.R.H., Cynthia, Lawrence, T. \& Nord, W.R. (Eds.), The SAGE Handbook of Organization Studies (2nd ed.). SAGE Publications, London, 215-254.

Lawrence, T.B., Suddaby, R., \& Leca, B., 2009. Introduction: Theorizing and studying institutional work. In: Leca, B., Suddaby, R., Lawrence, T.B. (Eds.), Institutional Work: Actors and Agency in Institutional Studies of Organizations. Cambridge University Press, Cambridge, 1-28.

Lounsbury, M. (2007). A tale of two cities: Competing logics and practice variation in the professionalizing of mutual funds. Academy of Management Journal, 50(2), 280-307.

Malhotra, N.K. (2012). Pesquisa de marketing: uma orientação aplicada (3rd ed.). Porto Alegre: Bookman.

Manyika, J., Lund, S., Bughin, J., Robinson, K., Mischke, J., \& Mahajan, D. (2016). Independent work: Choice, necessity, and the gig economy. McKinsey \& Company. October. available at: https:// www.mckinsey.com/featured-insights/employment-and-growth/independent-work-choicenecessity-and-the-gig-economy.

Martin, E., \& Shaheen, S. (2011). The impact of carsharing on public transit and nonmotorized travel: An exploration of North American carsharing survey data. Energies, 4(11), 2094-2114.

Mattsson, J., \& Barnes, S. (2016). Understanding current and future issues in collaborative consumption: A four-stage delphi study. Technological Forecasting and Social Change, 104, 200-211.

McNicoll, G. (2001). Fertility: Institutional and political approaches. Smelser, N.J. \& Baltes, P.B., (Ed) International Encyclopedia of the Social \& Behavioral Sciences: Pergamon, 5538-5543.

Meyer, J., \& Rowan, B. (1977). Institutionalized organizations: Formal structure as myth and ceremony. American Journal of Sociology, 83(2), 340-363.

Meyer, G., \& Shaheen, S. (2017). Disrupting mobility: Impacts of sharing economy and innovative transportation on cities: Cham: Springer, pp. 1-349.

Nelson, R., \& Winter, S. (1982). An evolutionary theory of economic change. Cambridge, MA: Belknap Press.

North, D. C. (1990). Institutions, institutional change and economic performance. Cambridge: Cambridge University Press.

North, D. C. (1991). Institutions. Journal of Economic Perspective. Pittsburgh, 5(1), 97-112.

North, D.C. (2006). Custos de Transação, Insituições e Desempenho Econômico, RJ (Brasil), Instituto Liberal.

Ocasio, W., Loewenstein, J., \& Nigam, A. (2015). How streams of communication reproduce and change institutional logics: the role of categories. Academy of Management Review, 40(1), 28-48.

Oliver, C. (1991). Strategic responses to institutional processes. Academy of Management Review, 16, 145-179. 
Perren, R., \& Kozinets, R.V. (2018). Lateral exchange markets: How social platforms operate in a networked economy. Journal of Marketing, 82(1), 20-36.

Perrien, J., Chéron, E.J. \& Zins, M. (1984). Recherche en marketing: Méthodes et décisions. Montreal: Gaetan Morin Editeur.

Peters, B. G. (2005). Institutional theory in political science: The new institutionalism. London: Continuum.

Institutional disruption and technology platforms

Pierson, P. (2004). Politics in time: History, institutions, and social analysis, Princeton, New Jersey, NJ: Princeton University Press.

Podsakoff, P.M., MacKenzie, S.B., \& Lee, J.Y. (2003). Common method biases in behavioral research: A critical review of the literature and recommended remedies. Journal of Applied Psychology, 88(5),879.

Powell, W.W., \& DiMaggio, P. (1991). The new institutionalism in organizational analysis.University of Chicago Press, Chicago.

Reay, T., \& Hinings, C.R. (2005). The recomposition of an organizational field: Health care in Alberta. Organization Studies, 26(3), 351-384.

Reckwitz, A. (2002). Towards a theory of social practice: A development in cultural theorizing. European Journal of Social Theory, 5(2), 243-63.

Roy, W.G. (1997). Socializing capital: The rise of the large industrial corporation in America. Princeton, New Jersey, NJ: Princeton University Press.

Sambiase, M.F., Teixeira, M.L.M., Bilskyb, W., de Araujo, B.F.V.B., \& De Domenicoa, S.M.R. (2014). Confrontando estruturas de valores: Um estudo comparativo entre PVQ-40 e PVQ-21. Psychology, 27(4),728-739.

Sauerland, D. (2015). Ideologies, institutions, and the new institutionalism, In Wright, J.D., International Encyclopedia of the Social \& Behavioral Sciences (2nd ed.). Elsevier, 2015, 561-572.

Schor, J.B., \& Attwood-charles, W. (2017). The sharing economy: Labor, inequality and sociability on for-profit platforms. Juliet B. Schor and william attwood-charles August 17. Sociology Compass, 11(8), e12493.

Schumpeter, J.A. (1942). Capitalism, socialism, and democracy. New York, NY: Harper and Brothers.

Scott, W.R. (1995). Institutions and organizations: Theory and research. London: Sage Publications.

Seo, M., \& Creed, W.E.D. (2002). Institutional contradictions, praxis, and institutional change: A dialectical perspective. Academy of Management Review, 27, 222-247.

Simon, H.A. (1947). Administrative behavior: a study of decision-making processes in administrative organizations (4th ed.). New York: Free Press.

Suddaby, R., \& Greenwood, R. (2005). Rhetorical strategies of legitimacy. Administrative Science Quarterly, 50, 35-67.

Sundararajan, A. (2016). The sharing economy: The end of employment and the rise of crowdbased capitalism. Cambridge, MA: MIT Press.

Sztompka, P. (1991). Society in action: The theory of social becoming. Cambridge: Polity Press.

Thelen K., \& Steinmo S. (1992). Historical institutionalism in comparative politics. In: Thelen K., Steinmo S., Longstreth F., (Ed.). Structuring Politics: historical institutionalism en comparative analysis. Cambridge: Cambridge University Press, pp.1-32.

Thornton, P. H., Ocasio, W., \& Lounsbury, M. (2012). The institutional logics perspective: A new approach to culture, structure and process. Oxford: Oxford University Press.

Todoli-Signes, A. (2017). The 'gig economy': Employee, self-employed or the need for a special employment regulation?, Transfer: European Review of Labour and Research, 23(2), 193-205.

Townley, B. (2002). The role of competing rationalities in institutional change. Academy of Management Journal, 45, 163-179.

Turner, S. (1994). The social theory of practices. Cambridge: Polity Press. 
Vaclavik, M.C., \& Pithan, L.H. (2018). The agency search: The meaning of work for app drivers. Revista de Administração Mackenzie, 19(5). doi:10.1590/1678-6971/eRAMG180080.

Villaschi Filho, A. (2005). Paradigmas tecnológicos: uma visão histórica para a transição presente. Revista de Economia, 30(1), 65-106.

Voss, T.R. (2015). Institutions. (Ed.) Wright, J.D., International Encyclopedia of the Social \& Behavioral Sciences (2nd ed.). Elsevier, pp. 190-195.

Williamson, O.E. (1985). Transaction cost economics. Handbook of industrial organization, 1, 135-182.

Wry, T., Cobb, J.A., \& Aldrich, H.E. (2013). More than a metaphor: assessing the historical legacy of resource dependence and its contemporary promise as a theory of environmental complexity. The Academy of Management Annals, 7(1), 441-488.

Zervas, G., Proserpio, D., \& Byers, J.W. (2017). The rise of the sharing economy: Estimating the impact of airbnb on the hotel industry. Journal of Marketing Research, 54(5), 687-705.

Zilber, T.B. (2006). The work of theSymbolic in institutional processes: Translationsof rational myths in Israeli high tech, Academy of Management Journal, 49(2), 281-303.

Zvolska L., Palgan Y.V., \& Mont O. (2019). How do sharing organisations create and disrupt institutions? Towards a framework for institutional work in the sharing economy, Journal of Cleaner Production, 219, 667-676.

\section{Corresponding author}

Wilquer Silvano de Souza Ferreira can be contacted at: wilquer1@hotmail.com

For instructions on how to order reprints of this article, please visit our website: 